\title{
The Correlation between Oral Health Knowledge \& Attitude towards Practice of Caretakers in Day-Care Centres
}

\author{
Noorhazayti Ab Halim ${ }^{1}$, Raihan Mastura Yusof ${ }^{1}$, Siti Norazizah Abdullah ${ }^{1}$
}

Kulliyyah of Dentistry, International Islamic University Malaysia Kuantan

\begin{abstract}
Modernization has made young children to spend most of their time in day-care centres as their mothers are working outside the home. Hence, the role of caretaker has become more important in the daily diet and oral health care of children. The objective of this study is to assess the oral health knowledge, attitude and practice among caretakers in day-care centres. A cross-sectional study among 54 caretakers aged 18 and above was conducted in Kuantan. The data was collected using a self-administered questionnaire addressing aspects of oral health knowledge, attitude and practice of caretakers. The results were analyzed by descriptive and Spearman correlation coefficient tests. The participants were mainly Malay ladies and $16.7 \%$ had university education. The knowledge of sugary food causing dental caries was found good for all caretakers; however, $48.1 \%$ of them do not know the important about filling the teeth of their children. Preliminary analysis was performed and followed by Spearman correlation coefficient analysis. Correlation between attitude and practice was weak ( $r h o=0.29, p<0.05)$, and between knowledge and practice ( $r h o=0.21, p>0.05$ ). The caretakers had good oral health knowledge but it did not reflect in their attitude and practices. The action must be based on knowledge, and that knowledge must produce action. As Abu Bakr (R.A) said, "without knowledge action is useless and knowledge without action is futile." The Arabic term " $\mathrm{ilm}$ translates to knowledge, but the word has a broader definition than its English counterpart. ' $/ \mathrm{lm}$ encompasses theory, action, and education whereas in English, knowledge is defined as merely the awareness of facts, truths, and principles.
\end{abstract}

KEYWORDS: Oral health knowledge, oral health attitude, oral health practice, caretaker, oral health.

\section{INTRODUCTION}

Maintaining a healthy lifestyle among children is very crucial for the general health and oral health as it influence their quality of life. One of the oral health problems of children is Early Childhood Caries (ECC). ECC is the diagnosis when there is presence of one or more decayed, missing (due to caries), or filled tooth surfaces in any primary tooth in a child under the age of $6 .^{1}$ The consequences of ECC are alterations of quality of life like chewing, eating, communication, playing, sleeping while restricting their potential of growth.

According to Malaysia National Oral Health Survey of Preschool Children (NOHPS), ${ }^{2}$ the mean decayed, missing, and filled teeth (dmft) among children below age 5 years old in 1999 and 2005 was 5.8 and 5.5 respectively. Thus the caries prevalence in 1999 was $87.1 \%$ and $76.2 \%$ in 2005 . There was only

Corresponding author:

Noorhazayti Ab. Halim

Kulliyyah of Dentistry

International Islamic University Malaysia,

Jalan Sultan Ahmad Shah, 25200 Kuantan

Telephone: $+609-5705457$

Fax: +609-5705580

Email: zetty@iium.edu.my a slight reduction in the prevalence of caries noted between those years.

The risk factors associated with ECC include low families income, cultural differences, irregular dental attender, inefficient oral hygiene care, lower educational level and lack of oral health knowledge among mothers. ${ }^{1}$ It is often agreed believed that mothers are the agent of change and source of early education. Therefore, many studies were done to assess the relationship between attitudes and believe of parents which lead to occurrence of ECC in their children.

Nowadays most of mothers are working, therefore their children have to stay most of the time at daycare centres. Hence, role of caretaker at day care centres has become more important because they have to prepare meal, general and oral hygiene practice of children.

According to Sahih al-Bukhārī 6719 (Saahaihn Muslim 1829), Allah's Messenger (PBUH) said, "Surely! Every one of you is a guardian and is responsible for his charges: The Imam (ruler) of the people is a guardian and is responsible for his subjects; a man is the guardian of his family (household) and is responsible for his subjects; a woman is the guardian of her husband's home and of his children 
and is responsible for them; and the slave of a man is a guardian of his master's property and is responsible for it." In this context, the caretaker is a guardian of the children in day-care centres and is responsible for them. Therefore, this study was conducted mainly to assess oral health knowledge, attitude and practice among caretakers at day-care centres.

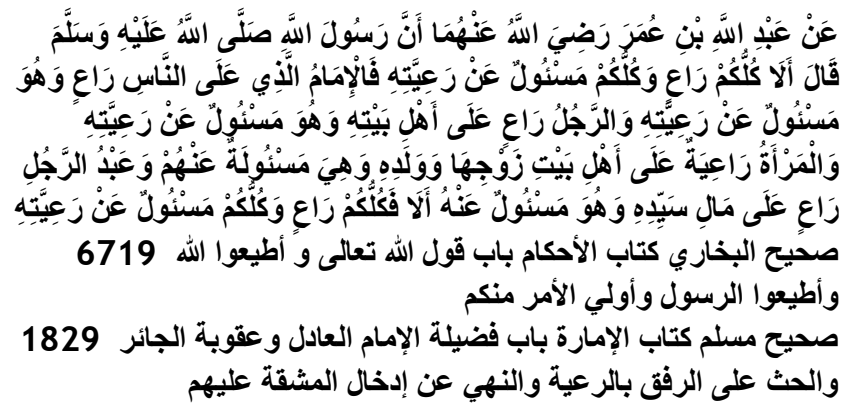

Source: Sahih al-Bukhāīi 6719, Sahih Muslim 1829

Grade: Muttafaqun Alayhi (authenticity agreed upon) according to Al-Bukhari and Muslim.

\section{MATERIALS AND METHODS}

A cross sectional study was conducted among caretakers of preschool children in day-care centres in Kuantan, Pahang. Ethical clearance was obtained from IIUM Research Ethics Committee (IIUM/305/14/11/2/IREC 406) and a written consent was obtained from participants. Ten day-care centres were randomly selected and the total participants involved in this study were 54 . The structured questionnaire was designed in English and was translated into Malay with reference to the study done by S.A Mani (2010). ${ }^{8}$ The questionnaires were translated forward and backward between two versions which were in Malay and English by the experts. However, all the questionnaires distributed were in the Malay version as requested by the respondents. A questionnaire consisted of two sections which were caretaker's general information and their knowledge, attitude and practices about the oral health of children. Pre-test of questionnaire was performed among 10 caretakers and they were not included in the real study. Sample size was calculated based on simple proportion formula.

$$
n=Z^{2} P(1-P) / d^{2}
$$

\section{$Z=1.96$ for $95 \%$ of the confidence interval}

$\mathrm{P}=$ expected prevalence $(0.97)$

$\mathrm{d}=$ precision at $5 \%$ with $95 \% \mathrm{Cl}$

$$
\mathrm{n}=1.96^{2} \times 0.97(1-0.97) / 0.05^{2}=45
$$

To account for an estimated response rate of $80 \%$, other $20 \%$ was added at data collection stage as follow:

$45+(45 \times 20 \%)=54$ caretakers

\section{DATA ANALYSIS}

The data obtained was analyzed using SPSS version 16.0 software system. The $P$ value was considered as significant when $<0.05$ (confidence interval of 95\%). Descriptive statistics was carried out to calculate responses for each question. Spearman's correlation test was performed in order to assess the relationship between oral health knowledge, attitude and practices.

\section{RESULTS}

A total of 54 caretakers completed the questionnaire with the mean age was $24.9 \pm 6.96$ years. The response of participants related to knowledge, attitude, and practices is presented in table 1, 2 and 3.

\section{Relationship between oral health knowledge,} attitude and practices.

The relationship between oral health knowledge and attitude towards practices was investigated using Pearson correlation coefficient. Preliminary analyses were performed to ensure no violation of the assumptions of normality, linearity and homoscedasticity. There was no violation of the assumptions of normality and linearity but there was violation of the assumptions in homoscedasticity. Therefore, the result of Spearman correlation coefficient test was used in this study.

As shown in the Table 4 ,there was a weak, positive correlation between attitude and practices (rho=0.29, $\mathrm{p}<0.05$ ). However, there was no significant association between oral health knowledge and practices which shown weak, positive correlation ( $r h o=0.21, p>0.05)$ as shown in Table 5. 
Table 1: Oral health knowledge of the caretakers.

\begin{tabular}{llll}
\hline \multicolumn{1}{c}{ Items } & True, (\%) & False, (\%) & Don't know, (\%) \\
\hline First tooth starts to appear in the mouth of child is at the & $43(79.6 \%)$ & $5(9.3 \%)$ & $6(11.1 \%)$ \\
$\begin{array}{l}\text { age of } 6 \text { months } \\
\text { Brushing baby's teeth is important for oral health }\end{array}$ & $43(79.6 \%)$ & $10(18.5 \%)$ & $1(1.9 \%)$ \\
Caries can affect infants below 2 years old & $31(57.4 \%)$ & $12(22.2 \%)$ & $11(20.4 \%)$ \\
$\begin{array}{l}\text { Fluoridated toothpaste is important for preventing caries in } \\
\text { teeth }\end{array}$ & $35(64.8 \%)$ & $6(11.1 \%)$ & $13(24.1 \%)$ \\
Weaning from a baby bottle to a sipping cup should be & $32(59.3 \%)$ & $15(27.8 \%)$ & $7(13.0 \%)$ \\
$\begin{array}{l}\text { planned as early as possible } \\
\text { Sugary/sticky food/drinks can cause caries }\end{array}$ & $54(100 \%)$ & 0 & 0 \\
It is not necessary to do filling in baby's teeth & $28(51.9 \%)$ & $14(25.9 \%)$ & $10(22.2 \%)$ \\
\hline
\end{tabular}

Table 2: Attitudes of caretakers toward child's oral health.

\begin{tabular}{|c|c|c|c|c|c|}
\hline Items & $\begin{array}{l}\text { Strongly } \\
\text { agree, } \mathrm{n} \\
(\%)\end{array}$ & $\begin{array}{l}\text { Agree, } \mathrm{n} \\
(\%)\end{array}$ & $\begin{array}{l}\text { Don't } \\
\text { know, n } \\
(\%)\end{array}$ & $\begin{array}{l}\text { Disagree, } \mathrm{n} \\
(\%)\end{array}$ & $\begin{array}{l}\text { Strongly } \\
\text { disagree, } \\
\mathrm{n}(\%)\end{array}$ \\
\hline A child's teeth should be cleaned/ brushed & $33(61.1 \%)$ & $20(37.0 \%)$ & 0 & $1(1.9 \%)$ & 0 \\
\hline $\begin{array}{l}\text { Effective cleaning of teeth brushing can be } \\
\text { achieved by the child him/herself }\end{array}$ & $2(3.7 \%)$ & $14(25.9 \%)$ & $6(11.1 \%)$ & 31 (57.4\%) & $1(1.9 \%)$ \\
\hline $\begin{array}{l}\text { A balanced diet is essential for the healthy } \\
\text { growth of a baby's teeth }\end{array}$ & $29(53.7 \%)$ & $20(37.0 \%)$ & $5(9.3 \%)$ & 0 & 0 \\
\hline $\begin{array}{l}\text { Tooth decay is caused by bacteria that are } \\
\text { transmitted by sharing feeding utensils (e.g.: } \\
\text { spoon) }\end{array}$ & $5(9.3 \%)$ & $11(20.4 \%)$ & $11(20.4 \%)$ & $22(40.7 \%)$ & $5(9.3 \%)$ \\
\hline $\begin{array}{l}\text { Frequent and prolonged bottle feeding can } \\
\text { cause tooth decay }\end{array}$ & $21(38.9 \%)$ & $21(38.9 \%)$ & $8(14.8 \%)$ & $4(7.4 \%)$ & 0 \\
\hline $\begin{array}{l}\text { Prolonged used of pacifier can affect the } \\
\text { normal development of a child's teeth }\end{array}$ & $14(25.9 \%)$ & $16(29.6 \%)$ & $19(35.2 \%)$ & $3(5.6 \%)$ & $2(3.7 \%)$ \\
\hline $\begin{array}{l}\text { Swallowing of toothpaste can be harmful to a } \\
\text { child's health }\end{array}$ & $2(3.7 \%)$ & $12(22.2 \%)$ & $10(18.5 \%)$ & $24(44.4 \%)$ & $6(11.1 \%)$ \\
\hline $\begin{array}{l}\text { It is important for a child to visit the dentist } \\
\text { after first eruption of teeth }\end{array}$ & $15(27.8 \%)$ & $19(35.2 \%)$ & $6(11.1 \%)$ & $12(22.2 \%)$ & $2(3.7 \%)$ \\
\hline
\end{tabular}

Table 3: The caretakers' practices of children oral health care.

\begin{tabular}{llll}
\hline Items & Always, n(\%) & Sometimes, n(\%) & Never, n(\%) \\
$\begin{array}{l}\text { Do you bite the food into small pieces before giving } \\
\text { to the children at the nursery? }\end{array}$ & $2(3.7 \%)$ & $14(25.9 \%)$ & $38(70.4 \%)$ \\
$\begin{array}{l}\text { How often did you do mouth examination on } \\
\text { children in nursery? }\end{array}$ & $25(46.3 \%)$ & $27(50.0 \%)$ & $2(3.7 \%)$ \\
$\begin{array}{l}\text { How often did you give sweet food to the children? } \\
\text { How often did you give sweetened liquid/juice to }\end{array}$ & 0 & $46(85.2 \%)$ & 8 (14.8\%) \\
the baby in bottle? & 0 & $14(25.9 \%)$ & $40(74.1 \%)$ \\
$\begin{array}{l}\text { How often did you give plain water after each feed? } \\
\text { How often do you clean a child's teeth at the }\end{array}$ & $51(94.4 \%)$ & $2(3.7 \%)$ & $13(1.9 \%)$ \\
$\begin{array}{l}\text { nursery? } \\
\text { Do you use pacifier dipped into sweet liquid for a } \\
\text { child? }\end{array}$ & 0 & $3.7 \%)$ \\
$\begin{array}{l}\text { Do you take the effort to improve your dental health } \\
\text { knowledge? }\end{array}$ & $23(42.6 \%)$ & $29(53.7 \%)$ & $51(94.4 \%)$
\end{tabular}


Table 4 :Spearman Correlations between Oral Health Attitude and Practices

\begin{tabular}{lccc}
\hline Spearman's rho & & Total practice & Total attitude \\
\hline Total practice & correlation coefficient & 1.000 & 0.289 \\
Sig. (2-tailed) & & & 0.034 \\
Total attitude & correlation coefficient & 0.289 & 1.000 \\
Sig. (2-tailed) & & 0.034 &. \\
\hline
\end{tabular}

Table 5 :Spearman Correlations between Oral Health Knowledge and Practices

\begin{tabular}{|c|c|c|}
\hline Spearman's rho & Total knowledge & Total practice \\
\hline $\begin{array}{l}\text { Total knowledge correlation coefficient } \\
\text { Sig. (2-tailed) }\end{array}$ & 1.000 & 0.210 \\
\hline Total practice correlation coefficient & 0.210 & $\begin{array}{l}0.128 \\
1.000\end{array}$ \\
\hline & 0.128 & - \\
\hline
\end{tabular}

${ }^{*}$ correlation is significant at the 0.05 level (2-tailed)

\section{DISCUSSION}

This cross-sectional study design took into consideration the manpower, money and time factor. Although the participants were not representative of the total population, however it gives baseline information regarding knowledge, attitude and practice among caretakers. There may have false-positive responses of participants as it were self-administered questionnaire.

The findings from this study showed a high proportion of caretakers had adequate level of oral health knowledge and its concurrent with others studies. ${ }^{3,4,5,8}$ This could be due to they had earlier information from school or other reading materials. Majority of them had knowledge on causes and prevention of dental caries and it is similar to findings that have been reported by $\mathrm{S}$. A. Mani et al. (2010), ${ }^{8}$ Vinay S et al. (2012) ${ }^{4}$ and Chan et al. (2002). ${ }^{5}$ It reflects that caretakers can implement the good oral health practices on the child under their care.

Most of the caretakers had an acceptable level of practice on frequency of giving plain water after each meal to the children (94.4\%) as recommended by the Malaysian Dietary Guideline for Children and Adolescents $(2013)^{9}$ that the children should drink an adequate amount of plain water daily agreeing with the findings of the $\mathrm{S}$. A. Mani (2010). ${ }^{8}$ Contrary to the reported findings in Bangalore study that $42 \%$ of the caretakers never make the children rinse their mouth with plain water after meal. ${ }^{4}$

About $85.2 \%$ of study participants acknowledged giving sweet food to the children and in accordance to findings that have been reported in S. A. Mani et al. (2010). ${ }^{8}$ Similar with findings from another study done in Kubang Kerian ${ }^{8}$ and Hyderabad, ${ }^{3}$ the caretakers never dipped child's pacifier in honey or sugar. However, in Bangalore $77 \%$ of them use pacifier dipped in honey or sugar when children acted troublesome. ${ }^{4}$

About half (52\%) of the participants in this study agreed that it was unnecessary for deciduous teeth to have fillings, and in accordance with findings in a study by S. A. Mani et al. (2010). ${ }^{8}$ A majority of participants in this study (96.3\%) did mouth examination in the children but $25.9 \%$ did not believe that it is important for a child to visit the dentist after first eruption of teeth. Therefore, caretakers should be trained to identify carious teeth as it is important to prevent its progression.

Although they had good oral health knowledge, however it did not reflect in their everyday practice. Good level of knowledge is probably due to they had earlier exposure to oral health education in school or other reading materials.

In perspective of Islam, all professions such as medical doctors, engineers, caretakers, employees in general are expected to have strength and trustworthy. It is to enable them to do their work with the commitment and responsibility. According to the Al-Quran, Surah Al-Qasas- verse 26 'One of the women said, "O my father, hire him. Indeed, the best one you can hire is the strong and the trustworthy." It shows that the best employees must have these two characters in order to avoid negligence in practice including caretakers. There is possibility that if the top management take oral health as a very important matter, oral health care enforcement for children among teachers will improve.

\section{CONCLUSION}

In this study, the caretakers had good oral health 
knowledge but it did not reflect in their attitude and practices. The action must be based on knowledge, and that knowledge must produce action. As Abu Bakr (R.A.) said, "without knowledge action is useless and knowledge without action is futile." The Arabic term "ilm translates to knowledge, but the word has a broader definition than its English counterpart. ' $/ l m$ encompasses theory, action, and education whereas in English, knowledge is defined as merely the awareness of facts, truths, and principles.

The results of this study cannot be extrapolated as the sample size was small and the study included only those caretakers who were working at Indera Mahkota, Kuantan. Hence, studies exploring the same issue need to be conducted on larger samples covering different populations so as to evaluate, which strategies will be effective and efficient in bringing about a behaviour change in caretakers.

Therefore, the implementation of oral health promotion programs in day-care centres is highly recommended in order to tackle oral health problems in children especially early childhood caries. It is important to ensure that caretakers had good oral heath knowledge, education, as well as good oral health attitude and practice.

\section{REFERENCES}

1. American Academy of Pediatric Dentistry. Policy on Early Childhood Caries (ECC): Classifications, Consequences, and Preventive Strategies 2011.

2. Oral Health Division, Ministry of health Malaysia. The National Oral Health Survey of Preschool Children 2005.

3. Reddy P, Anjum MS, Monica M, Yadav K, Abbas I, Kanakamedala S. Evaluation of oral health knowledge among caretakers working in baby day care centers of greater Hyderabad. Webmed Central PUBLIC HEALTH 2014; 5(10).

4. Vinay S, Naveen N, Naganandini N. Feeding and Oral Hygiene Habits of children attending daycare centers in Bangalore and their caretaker's oral health knowledge, attitude and practices. Indian J Dent Res 2012.

5. Chan SCL, Tsai JSJ, King NM. Feeding and oral hygiene habits of preschool children in Hong Kong and their caregivers' dental knowledge and attitudes. International Journal of Paediatric Dentistry 2002; 12 (5):322-31.

6. Oredugba F, Maarufah A, Oladipo A, Adebayo 0. 2014. Assessment of Mothers' Oral Health Knowledge: Towards Oral Health Promotion for Infants and Children. Health 2014; 6: 908-15.

7. Romi J, Kunal CO, Rajeev C. Knowledge, attitude and practices of mothers toward their children's oral health: A questionnaire survey among subpopulation in Mumbai (India). Journal of Dental Research and Scientific Development 2014.

8. SA Mani, AA Aziz, J John, NM Ismail. Knowledge, attitude and practice of oral health promoting factors among caretakers of children attending day-care centers in Kubang Kerian, Malaysia: A preliminary study. J Indian Soc Pedod Prev Dent 2010; 28(2):78-83.

9. Malaysian Dietary Guideline for Children and Adolescents. National Coordinating Committee on Food and Nutrition. Ministry of Health Malaysia 2013. 
